Copyright 2002 by the Mycological Society of America. Eaton, G. K. \& Ayres, M. P. (2002). Plasticity and constraint in growth and protein mineralization of ectomycorrhizal fungi under simulated nitrogen deposition. Mycologia, 94(6), 921-932. doi: 10.2307/3761860. Retrieved from: http://www.mycologia.org/content/94/6/921.abstract?sid=13acfd59-0c12-40da-a408-110f61a7f38d

Mycologia, 94(6), 2002, pp. 921-932.

(C) 2002 by The Mycological Society of America, Lawrence, KS 66044-8897

\title{
Plasticity and constraint in growth and protein mineralization of ectomycorrhizal fungi under simulated nitrogen deposition
}

\author{
Gregory K. Eaton ${ }^{1}$ \\ Department of Horticulture, Virginia Tech, Blacksburg, \\ Virginia 24061 \\ Matthew P. Ayres \\ Department of Biological Sciences, Dartmouth College, \\ Hanover, New Hampshire 03755
}

Abstract: Ectomycorrhizal fungi allow their host plants access to organic forms of $\mathrm{N}$ through enzymatic mineralization of the substrate and enhanced absorption of amino acids and mineral $\mathrm{N}$. The cost to the plant is carbohydrates that support fungal growth and metabolism. Enrichment of soils with mineral $\mathrm{N}$, as through atmospheric deposition, may affect the growth and function of these fungi by direct effects of increased $\mathrm{N}$ availability on fungi and indirect effects through reduced plant $\mathrm{C}$ allocation to roots. We tested the potential of $\mathrm{N}$ enrichment and altered carbohydrate supply to affect the growth and protein mineralization activity of 10 ectomycorrhizal fungi in sterile liquid media. Nitrogen treatments consisted of organic $\mathrm{N}$ only vs organic plus mineral N. Carbon treatments consisted of $5 \mathrm{~g}$ per liter glucose vs. no glucose added. Fungi differed widely in their growth and mineralization responses to these variables. Seven of 10 fungi had at least $20 \%$ reduced growth with reduced carbohydrates. Only 2 of 10 increased growth by $20 \%$ or more with increased mineral N. Carbohydrates affected growth more in a purely organic $\mathrm{N}$ environment suggesting an energy limitation to mineralization. Protein mineralization activity tended to be depressed by reductions in carbohydrates and increased by increased mineral $\mathrm{N}$. The high sensitivity of fungal growth to carbohydrates suggests important indirect effects of $\mathrm{N}$ enrichment via altered $\mathrm{C}$ allocation in host trees. Principal Components analysis separated most fungal species along an axis representing a gradient from high protein mineralization efficiency to high intrinsic growth rate. Those fungi with slow growth and efficient mineralization activity corresponded closely to fungi often cited as late successional species, while fungi with high growth rates and low mineralization efficiency are often categorized as early successional.

Accepted for publication March 21, 2002.

${ }^{1}$ Corresponding author, Email: geaton@vt.edu
One fungus, Cenococcum geophillum, separated from others on an axis representing strong $\mathrm{N}$ dependence in growth. Nitrogen enrichment has the potential to alter the composition and function of the ectomycorrhizal fungus community. Physiological differences among species provide a starting point for predicting community responses and anticipating ecosystem consequences.

Key Words: atmospheric deposition, carbon-nitrogen interactions, mineralizing enzymes, nitrogen enrichment, protease

\section{INTRODUCTION}

Ectomycorrhizal fungi are important symbionts of many temperate forest trees. The symbiosis is considered to be an adaptation of trees to acquire soil nutrients and of fungi to acquire carbohydrates (Smith and Read 1997). In nutrient-limited environments, plants allocate relatively more carbohydrates to roots (Schulze and Chapin 1987, Vogt et al 1993). Some root carbohydrates reach the rhizosphere, which supports a diverse community of microorganisms, including mycorrhizal fungi. The metabolic activity of soil flora enhances the availability of soil nutrients through mineralization. Ectomycorrhizal fungi are particularly beneficial to plants because they produce ectoenzymes that mineralize organic compounds and facilitate the transfer of acquired nutrients to the tree host via intimate associations with the cortex of roots (Dighton 1991, Näsholm et al 1998).

It is estimated that the support of mycorrhizal fungi can cost the tree as much as $15 \%$ of net primary productivity (Fogel and Hunt 1979, Vogt et al 1982, Finlay 1992). Because the energy and C skeletons for the production of nutrient-mobilizing enzymes may originate from the plant host (Dighton 1991), fungi that produce more of these enzymes could do so at an increased cost to the plant. In nutrient-poor environments, the increased cost of fungal enzyme production can be to the plant's advantage, because this also increases mineralization of the more limiting soil nutrients (Dighton 1991, Sinsabaugh et al 1993, Sinsabaugh and Moorhead 1994). However, the relative benefit achieved by the plant in this relationship could easily change with soil fertility. The benefits to plants of mycorrhizal fungi may become less in en- 
vironments where mineral nutrients are more available for direct absorption by the plant. The persistence of mycorrhizal fungi in fertile environments should depend on 1) effects of increased soil fertility on carbohydrate pools in host plant roots, 2) effect of nutrient concentrations and chemical form on fungal growth and colonization, 3) plasticity of responses by component fungi to alterations in these resources, and 4) attributes of the specific fungal species that are present with regard to carbon costs and nutrient benefits.

Ectomycorrhizal fungi tend to be important components of the microbial community in most temperate forests where $\mathrm{N}$ has historically been a primary limiting nutrient (Vitousek et al 1997). Nitrogen enrichment of these soils through atmospheric deposition (Aber 1992, Jefferies and Maron 1997) may reduce the abundance (Termorshuizen and Schaffers 1987, 1991) and diversity (Ohenoja 1988, Kuyper and de Vries 1990, Arnolds 1991, Gulden et al 1993) of ectomycorrhizal fungi, and alter their community composition (Lilleskov et al 2001). The physiological and ecological mechanisms behind this phenomenon are still debated (Chalot and Brun 1998, Wallenda and Kottke 1998), but it has been interpreted as a consequence of adaptations of ectomycorrhizal fungi to N-limited forests (Arnolds 1988, Read 1991). Plant growth and allocation responses to N-enrichment are well established (Chapin 1980, Herms and Mattson 1992, Ayres 1993) and generally include increased root and shoot growth, a decrease in root: shoot biomass, and reduced levels of soluble carbohydrates in roots and in the surrounding rhizosphere (Vogt et al 1993, Wallenda et al 1996). Nitrogen enrichment of soils presents a conundrum of potentially conflicting resource pressures for ectomycorrhizal fungi. Most ectomycorrhizal fungi respond to increased mineral $\mathrm{N}$ with increased growth (France and Reid 1984, Plassard et al 1991, Baar et al 1997). Most also respond to decreased carbohydrate supply with decreased growth. The interactions between $\mathrm{N}$ and C supply should therefore be of considerable importance in determining the growth of these fungi in environments experiencing $\mathrm{N}$-enrichment (France and Reid 1983).

In addition to growth responses associated with $\mathrm{N}$ enrichment, fungi may also change in their production of extracellular enzymes, which may alter their function in soil biogeochemistry. There are many reports of increased mineralization rates in soils with $\mathrm{N}$ enrichment and these imply that microbial activity in N-enriched soils is increased (Gundersen 1998, Diekmann et al 1999). Chronic deposition of atmospheric $\mathrm{N}$ can also lead to decreased mineralization rates (McNulty and Aber 1993). Nitrogen enrichment has been reported to both increase and decrease protease activity (Leake and Read 1991, Zhu et al 1994, Dunne et al 1997, Zaman et al 1999). Protease activity is fundamental to soil $\mathrm{N}$ mineralization (Dighton 1991, Sinsabaugh 1994, Zaman et al 1999). There may be additional indirect effects of $\mathrm{N}$ enrichment on enzyme production because of changes in C supply rates from host trees, e.g., through catabolite repression and derepression (Zhu et al 1994 and references therein). Increased concentrations of simple sugars can repress protease activity in fungi (Cohen 1981), but enzyme production can be energy limited so decreases in carbohydrate supply could also decrease fungal enzyme production (Zhu et al 1994).

In this paper we explored the range of growth and protein mineralization responses of 10 common ectomycorrhizal fungi to a factorial design of $\mathrm{N}$ and carbohydrate enrichment designed to simulate expected changes under $\mathrm{N}$ enrichment. We tested the hypotheses that mineral $\mathrm{N}$ enrichment will increase fungal growth and alter ectoprotease activity, decreased C supply will decrease the growth and ectoprotease activity of these fungi, and interactions between $\mathrm{C}$ and $\mathrm{N}$ supply will be important in determining the physiological responses of fungi. We predicted differences between fungal species in their growth and ectoprotease responses to carbohydrates and $\mathrm{N}$. These hypotheses are germane to understanding the consequences of $\mathrm{N}$ enrichment for individual fungus species, ectomycorrhizal communities, and ecosystem processes.

\section{METHODS}

Fungi were obtained from cultures maintained at the Virginia Tech Culture Collection, or from cultures isolated from fruiting bodies collected on Mt. Ascutney, Vermont, or Burnt Mt. Recreation Area, Lebanon, New Hampshire. All were maintained on modified Hagem's agar medium prior to the experiment. This medium contained the fol-

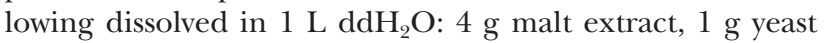
extract, $5 \mathrm{~g}$ D-Glucose, $0.5 \mathrm{~g} \mathrm{NH}_{4} \mathrm{Cl}, 0.5 \mathrm{~g} \mathrm{KH}_{2} \mathrm{PO}_{4}, 0.5 \mathrm{~g}$ $\mathrm{MgSO}_{4} \cdot 7 \mathrm{H}_{2} \mathrm{O}, 0.5 \mathrm{~mL} \mathrm{FeCl}_{3}$ (1\% aqueous solution), $100 \mu \mathrm{L}$ Biotin $(50 \mu \mathrm{g} / \mathrm{mL}$ aqueous solution), $100 \mu \mathrm{L}$ Thiamine (1 $\mathrm{mg} / \mathrm{mL}$ aqueous solution), $15 \mathrm{~g}$ agar. All species are common ectomycorrhizal fungi with a broad host range (except Leccinum scabrum, reported only from Betula spp.) that represent a range of ecological characteristics in nature. Cenococcum geophillum and Piloderma bicolor are considered multi-stage fungi (Visser 1995, Bradbury et al 1998, Jonsson et al 1999), colonizing seedlings or mature host plants in many environments. Amanita spp. (Hintikka 1988, SennIrlet and Bieri 1999) and Lactarius spp. (Mason et al 1983, Dighton et al 1986, Last et al 1987) are considered latestage fungi that typically colonize hosts in mature, relatively undisturbed forests.

Media for the experiment consisted of liquid Hagem's 
medium modified to provide $\mathrm{N}$ in either organic form (Bovine Serum Albumin (BSA), a pure protein), or organic plus mineral $\mathrm{N}\left(\mathrm{BSA}+\mathrm{NH}_{4} \mathrm{NO}_{3}\right)$ in a factorial design with high and low carbohydrate concentrations in the form of glucose (the primary carbon source transferred from plant to fungus; Smith and Smith 1990). Base medium included: $1 \mathrm{~g}$ yeast extract, $4 \mathrm{~g}$ malt extract, $0.5 \mathrm{~g} \mathrm{KH}_{2} \mathrm{PO}_{4}, 0.5 \mathrm{~g}$ $\mathrm{MgSO}_{4} \cdot 7 \mathrm{H}_{2} \mathrm{O}, 0.683 \mathrm{~g} \mathrm{CaCl}_{3} \cdot 2 \mathrm{H}_{2} \mathrm{O}, 0.5 \mathrm{~mL} \mathrm{FeCl}_{3}$ (1\% aqueous solution), $100 \mu \mathrm{L}$ Biotin ( $50 \mu \mathrm{g} / \mathrm{mL}$ aqueous solution), $100 \mu \mathrm{L}$ Thiamine $(1 \mathrm{mg} / \mathrm{mL}$ aqueous solution $)$ in $1 \mathrm{~L}$ $\mathrm{ddH}_{2} \mathrm{O}$. Mineral $\mathrm{N}$ media contained $0.37 \mathrm{~g} \mathrm{NH}_{4} \mathrm{NO}_{3} / \mathrm{L}$. High carbohydrate media included $5 \mathrm{~g} / \mathrm{L}$ D-glucose; low carbohydrate treatments included no added D-glucose. All media were adjusted to $\mathrm{pH} 4.5$ with $1 \mathrm{~N} \mathrm{H}_{2} \mathrm{SO}_{4}$, dispensed to $125 \mathrm{~mL}$ flasks in $20 \mathrm{~mL}$ aliquots and autoclaved. All flasks received organic $\mathrm{N}$ in the form of $1 \mathrm{~mL}$ of $40.5 \mathrm{mg} / \mathrm{mL}$ filter-sterilized BSA stock solution. To summarize the experimental environments in each flask (20 mL media):

- Organic N treatments had $8.28 \mathrm{mg}$ of total $\mathrm{N}-86.6 \%$ (7.18 mg N per flask) was amino N (88\% of amino N from BSA, remainder from amino $\mathrm{N}$ in yeast extract), $13.3 \%$ (1.1 mg N per flask) was mineral $\mathrm{N}$ from yeast extract.

- Organic + mineral $\mathrm{N}$ treatments had $10.87 \mathrm{mg}$ of total $\mathrm{N}, 31 \%$ more total $\mathrm{N}$ than the organic $\mathrm{N}$ treatment, all from mineral $\mathrm{NH}_{4} \mathrm{NO}_{3}$.

- Low carbohydrate treatments had $7.12 \mathrm{mg}$ glucose and $46.5 \mathrm{mg}$ other sugars, all from malt extract.

- High carbohydrate treatments had additional $100 \mathrm{mg}$ glucose (3 fold increase in total sugars, 15 fold increase in glucose).

Each flask was inoculated with 1 plug of mycelium in Hagem's agar isolated from the leading edge of actively growing cultures with a sterile \#3 cork borer (6 mm i.d.) and incubated in the dark at $25 \mathrm{C}$. Each species was represented by 4-8 replicate cultures within each of the four treatment combinations. Fungal colonies were harvested after $48 \mathrm{~d}$, except for the four fastest-growing species that were harvested after $32 \mathrm{~d}$ to minimize affects from resource depletion.

At harvest, each flask was filtered through a $0.45 \mu \mathrm{m}$ membrane filter. Mycelium collected on the filter was dried at $60 \mathrm{C}$ and weighed. Relative growth rates were calculated as $\mathrm{mg}$ mycelium $* \mathrm{mg}^{-1} * \mathrm{~d}^{-1}$ : $\left(\ln \mathrm{M}_{\mathrm{f}}-\ln \mathrm{M}_{\mathrm{i}}\right) / \mathrm{t}$, where $\mathrm{M}_{\mathrm{f}}$ = final mass, $\mathrm{M}_{\mathrm{i}}=$ initial mass (estimated as $0.2 \mathrm{mg}$ for all), and $\mathrm{t}=$ time in days. Filtrate was frozen in a dry ice ethanol bath and stored at $-20 \mathrm{C}$. Protease ectoenzyme activity in filtrates was estimated by analysis of residual protein using Bradford's reagent (Sigma Chemical Co.). Filtrate subsamples were thawed and $100 \mu \mathrm{L}$ was pipetted into test tubes. Bradford's reagent was added to each in $5 \mathrm{~mL}$ aliquots and mixed. Absorbance was read at $595 \mathrm{~nm}$ (Milton Roy spectrophotometer, model 301). A standard curve was developed using known amounts of BSA in $\mathrm{dd}_{2} \mathrm{O}$ and likewise mixed with Bradford's reagent. Residual protein concentrations of unknowns were computed from the standard curve. We calculated $\mathrm{mg}$ of protein mineralized by the culture by subtracting final from initial concentration. We calculated efficiency of protein mineralization as mg BSA mineralized per mg final mass mycelium.
A 3-way ANOVA was used to test for effects of carbohydrate, $\mathrm{N}$ and species on fungal growth and protein mineralization efficiency. Protein mineralization efficiency was transformed (ln (efficiency +1$)$ ) to correct for heteroscedascity. ANOVA was performed using JMP software (SAS Institute Inc., Cary, North Carolina). Efficiency of protein mineralization was also analyzed visually by plotting average protein mineralized vs total growth in all treatment combinations combined for each fungus. A principal components analysis (PCA) was employed to evaluate covariation among fungi in their growth and protein mineralization responses to carbohydrates and mineral N. PCA was performed using Number Cruncher Statistical Software (NCSS) (Hintz 2002). Dependant variables for the PCA were parameter coefficients for each species from the conventional linear model of a 2-way ANOVA:

$$
\begin{aligned}
\mu_{i j}= & \mu . .+\alpha_{i}+\beta_{j} \\
& +(\alpha \beta)_{i j} \text { Eq. } 1 \text { (p. 568, Neter and Wasserman 1974) }
\end{aligned}
$$

where $\mu .$. is the mean growth or protein mineralization efficiency of each fungus over all treatments, $\alpha_{i}$ is the main effect of $\mathrm{C}$ treatment, $\beta_{j}$ is the main effect of $\mathrm{N}$, and $(\alpha \beta)_{i j}$ is the interaction effect of $\mathrm{C}$ and $\mathrm{N}$. These variables were well suited for PCA analysis because they are parsimoniously estimated by least squares regression, are mathematically independent of each other and allowed us to partition the treatment effects in a way that matched our experimental design.

\section{RESULTS}

There were large differences between fungi in growth and protein mineralization responses to $\mathrm{N}$ enrichment and supplemented carbohydrates. All main effects and interaction terms in the 3-way ANOVA were highly significant for growth and all but $\mathrm{C}$ $\times \mathrm{N}$ interaction were significant for protein mineralization efficiency (TABLE I). Most fungi responded to increased carbohydrate supply with increased growth rate ( $\geq 20 \%$ increase in 7 of 10 species). Only 4 of 10 species responded with increased protein mineralization (Amanita spp and Lactarius indigo, TABLE II). Most fungi (7 of 10) responded to the addition of mineral $\mathrm{N}$ in the medium with increased protein mineralization, but only 2 responded with appreciable $(\geq 20 \%)$ increases in growth $(A$. rubescens, C. geophillum, TABLE II). Across all fungi, the addition of mineral $\mathrm{N}$ had a stronger effect on growth and protein mineralization when carbohydrates were limiting, and the addition of glucose had a stronger effect in the absence of mineral N (FIG. 1A, B; $\mathrm{C} \times$ $\mathrm{N}$ interaction, TABLE I).

There was a positive relationship across fungi between growth and protein mineralization (FIG. 2A). Three fungi tended to have higher protein mineralization than expected based on their growth (Inocybe 
TABLE I. Results of 3-way ANOVA testing for effects of carbohydrates and mineral nitrogen on relative growth rate and protein mineralization efficiency of 10 ectomycorrhizal fungi

\begin{tabular}{|c|c|c|c|c|}
\hline \multirow[b]{2}{*}{ Effect } & \multicolumn{2}{|c|}{ Relative growth rate } & \multicolumn{2}{|c|}{$\begin{array}{c}\text { Protein } \\
\text { mineralization } \\
\text { efficiency }^{\mathrm{b}}\end{array}$} \\
\hline & $\mathrm{df}$ & $\mathrm{F}$ & df & $\mathrm{F}$ \\
\hline Species & 9 & $5328.34 * * *$ & 9 & $77.47 * * *$ \\
\hline Carbohydrate & 1 & $347.86^{* * *}$ & 1 & $64.51 * * *$ \\
\hline Nitrogen & 1 & $103.79 * * *$ & 1 & $127.70 * * *$ \\
\hline $\mathrm{C} \times \mathrm{N}$ & 1 & $140.3^{* * *}$ & 1 & 0.53 \\
\hline $\mathrm{S} \times \mathrm{C}$ & 9 & $44.08 * * *$ & 9 & $25.19 * * *$ \\
\hline $\mathrm{S} \times \mathrm{N}$ & 9 & $35.17 * * *$ & 9 & $19.53 * * *$ \\
\hline $\mathrm{S} \times \mathrm{C} \times \mathrm{N}$ & 9 & $19.48 * * *$ & 9 & $9.21 * * *$ \\
\hline Error $^{\mathrm{c}}$ & 175 & & 175 & \\
\hline
\end{tabular}

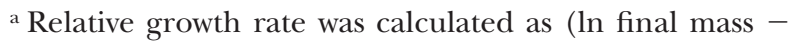
ln initial mass)/time in days.

b Protein mineralization efficiency was calculated as total protein mineralized per mg final mass of mycelium.

${ }^{\mathrm{c}}$ MSE for the two ANOVA models were 0.000013 and 0.019 for growth and protein mineralization efficiency, respectively.

$* * * P<0.001$.

dulcamera, Amanita rubescens and Scleroderma citrina) indicating that they produce relatively large amounts of protease on a mycelial mass basis. In contrast, Leccinum scabrum and Cenococcum geophillum appeared to produce less protease on a mass basis. There was no obvious relationship across fungi between relative growth rate and protein mineralization efficiency (mycelial mass basis, FIG. 2B) although a negative trend was suggested and in this measure also $A$. rubescens and $A$. pantherina were efficient protease producers. This relationship was not statistically significant.

There were numerous correlations across species in physiological responses to glucose and mineral $\mathrm{N}$ (TABLE III). The first three axes of a principal components analysis explained $77 \%$ of the variation. PC axis 1 represented a gradient from high mineralization efficiency to high relative growth rate (TABLE IV), these traits being strongly negatively correlated (TABLE III). Fungi categorized a priori as late-stage colonizers segregated toward high mineralization efficiency, whereas those categorized as early-stage fungi tended toward high growth rate (FIG. 3). Axis 2 (not illustrated) grouped fungi based primarily on the strength and type of $\mathrm{C} \times \mathrm{N}$ interaction in mineralization efficiency response. On this axis the most remarkable separation occurred between Amanita pantherina with a very strong mineral $\mathrm{N}$ response only when carbohydrates were plentiful, and $A$. rubescens which responded to mineral $\mathrm{N}$ only when carbon was limiting (TABLE II). Axis 3 represents a gradient from low to high growth response to mineral N (TABle IV). Cenococcum geophillum separated strongly on PC axis 3 reflecting its very high sensitivity in growth to mineral $\mathrm{N}$.

\section{DISCUSSION}

The direct growth responses of ectomycorrhizal fungi to enrichment by mineral $\mathrm{N}$ varied greatly. While six fungi did not respond, the two that did responded so strongly that the overall effect of $\mathrm{N}$ on growth across all fungi was highly significant. Apparently, mineral $\mathrm{N}$ was limiting to the growth of some fungi but not others. This suggests that addition of mineral $\mathrm{N}$ alone could change the competitive interactions among these fungi. Nitrogen enrichment generally stimulated enzyme activity, indicating that mineral $\mathrm{N}$ is more commonly limiting to protease synthesis than to growth. This is consistent with field and laboratory studies showing a stimulation of fungal metabolism by $\mathrm{N}$ additions, e.g., mineralization rates (Hatch et al 2000, Jonasson and Michelson 1996) and respiration rates (Ohtonen 1994, Ek 1997, Hatch et al 2000), but only small increases (Carreiro et al 1996), no change (Hatch et al 2000) or net decreases (Ohtonen 1994, Bardgett and McAlister 1999) in microbial biomass. Our study of ten species included only one case (Leccinum scabrum) when mineral $\mathrm{N}$ inhibited protease activity (but see Zhu et al 1994). In some fungi, e.g., Amanita pantherina and Lactarius spp, mineral $\mathrm{N}$ addition decreased growth while increasing protein mineralization efficiency. For these fungi, the stimulation of protein mineralization activity apparently came at a cost to growth.

Reduction in carbohydrate supply decreased the growth of most fungi, though surprisingly, two species grew significantly less in the presence of mineral $\mathrm{N}$ when glucose was added to the media (A. pantherina, $P$. bicolor). If these growth reductions were due to glucose (catabolite) repression of enzyme activity (Leake and Read 1991), they should have been correlated with reductions in enzyme activity. This was not the case for either of these fungi. These cases may be understood as the result of altered $\mathrm{C}$ allocation in an environment enriched with mineral $\mathrm{N}$, whereby more $\mathrm{C}$ is allocated to $\mathrm{N}$ uptake (as energy) and amino acid synthesis (as energy and carbon skeletons), leaving less $\mathrm{C}$ available for growth (Wallander 1995, Wallander et al 1999, Bidartondo et al 2001).

Additional glucose stimulated growth most in treatments lacking mineral $\mathrm{N}$ (significant $\mathrm{C} \times \mathrm{N}$ interaction, TABLE I). These patterns suggest some resource 
TABLE II. Mean (SE) growth rate and protein mineralization efficiency for 10 species of ectomycorrhizal fungi grown in different carbohydrate and nitrogen environments. $\mathrm{N}=4-8$ for each mean

\begin{tabular}{|c|c|c|c|}
\hline & $\begin{array}{c}\text { Medium } \\
\text { (sugar, nitrogen) }\end{array}$ & $\begin{array}{c}\text { Growth rate } \\
\left(\mathrm{mg}^{*} \mathrm{mg}^{-1 *} \mathrm{~d}^{-1}\right)\end{array}$ & $\begin{array}{l}\text { Protein mineralization } \\
\text { efficiency }\left(\mathrm{mg}^{*} \mathrm{mg}^{-1}\right)\end{array}$ \\
\hline \multirow[t]{4}{*}{ Amanita muscaria } & low, org. & $0.500(0.0009)$ & 0 \\
\hline & low, org. $+\min$. & $0.051(0.0016)$ & 0 \\
\hline & high, org. & $0.068(0.0027)$ & $0.08(0.06)$ \\
\hline & high, org. $+\min$. & $0.078(0.0046)$ & $0.44(0.14)$ \\
\hline \multirow{4}{*}{ Amanita pantherina var. velatipes. } & low, org. & $0.050(0.0021)$ & $0.01(0.08)$ \\
\hline & low, org. $+\min$. & $0.061(0.0018)$ & $0.93(0.08)$ \\
\hline & high, org. & $0.076(0.0022)$ & $0.87(0.15)$ \\
\hline & high, org. $+\min$. & $0.062(0.0021)$ & $4.12(0.39)$ \\
\hline \multirow[t]{4}{*}{ Amanita rubescens } & low, org. & $0.057(0.0018)$ & $0.48(0.17)$ \\
\hline & low, org. $+\min$. & $0.083(0.0026)$ & $3.34(0.29)$ \\
\hline & high, org. & $0.087(0.0015)$ & $2.77(0.23)$ \\
\hline & high, org. $+\min$. & $0.090(0.0013)$ & $2.52(0.15)$ \\
\hline \multirow[t]{4}{*}{ Cenococcum geophillum } & low, org. & $0.091(0.0006)$ & $0.11(0.05)$ \\
\hline & low, org. $+\min$. & $0.123(0.0009)$ & $0.41(0.02)$ \\
\hline & high, org. & $0.096(0.0005)$ & $0.02(0.01)$ \\
\hline & high, org. $+\min$. & $0.118(0.0005)$ & $0.32(0.04)$ \\
\hline \multirow[t]{4}{*}{ Inocybe dulcamera } & low, org. & $0.174(0.0016)$ & $0.77(0.04)$ \\
\hline & low, org. $+\min$. & $0.171(0.0018)$ & $0.86(0.05)$ \\
\hline & high, org. & $0.181(0.0020)$ & $0.61(0.04)$ \\
\hline & high, org. $+\min$. & $0.179(0.0008)$ & $0.65(0.02)$ \\
\hline \multirow[t]{4}{*}{ Lactarius hepaticus } & low, org. & $0.051(0.0019)$ & $0.23(0.23)$ \\
\hline & low, org. $+\min$. & $0.056(0.0016)$ & $0.74(0.49)$ \\
\hline & high, org. & $0.068(0.0008)$ & $0.005(0.005)$ \\
\hline & high, org. $+\min$. & $0.062(0.0013)$ & $0.29(0.13)$ \\
\hline \multirow[t]{4}{*}{ Lactarius indigo } & low, org. & $0.059(0.0012)$ & 0 \\
\hline & low, org. $+\min$. & $0.083(0.0030)$ & $0.38(0.22)$ \\
\hline & high, org. & $0.096(0.0036)$ & $0.68(0.07)$ \\
\hline & high, org. $+\min$. & $0.093(0.0047)$ & $1.15(0.12)$ \\
\hline \multirow[t]{4}{*}{ Leccinum scabrum } & low, org. & $0.168(0.0006)$ & $0.59(0.01)$ \\
\hline & low, org. $+\min$. & $0.173(0.0005)$ & $0.44(0.01)$ \\
\hline & high, org. & $0.175(0.0013)$ & $0.51(0.02)$ \\
\hline & high, org. $+\min$. & $0.175(0.0006)$ & $0.49(0.01)$ \\
\hline \multirow[t]{4}{*}{ Piloderma bicolour } & low, org. & $0.190(0.0007)$ & $0.38(0.01)$ \\
\hline & low, org. $+\min$. & $0.206(0.0004)$ & $0.29(0.003)$ \\
\hline & high, org. & $0.214(0.0006)$ & $0.19(0.005)$ \\
\hline & high, org. $+\min$. & $0.196(0.0004)$ & $0.40(0.005)$ \\
\hline \multirow[t]{4}{*}{ Scleroderma citrina } & low, org. & $0.182(0.0009)$ & $0.59(0.02)$ \\
\hline & low, org. $+\min$. & $0.182(0.0006)$ & $0.60(0.01)$ \\
\hline & high, org. & $0.172(0.0003)$ & $0.82(0.008)$ \\
\hline & high, org. $+\min$. & $0.172(0.0004)$ & $0.83(0.01)$ \\
\hline
\end{tabular}

substitutability (Bloom et al 1985, Sinclair and Park 1993) of $\mathrm{C}$ and $\mathrm{N}$ in the physiology of these fungi, i.e., C limitations (indicated by lower growth in low sugar treatments) are eased by the addition of mineral N. Both $\mathrm{C}$ and $\mathrm{N}$ are important components of fungal mycelium and of ectoenzymes and so can be limiting resources. Carbon and nitrogen cannot be substituted for each other at the molecular level but mineral $\mathrm{N}$ can apparently be employed by fungi to acquire from elsewhere the $\mathrm{C}$ skeletons and/or en- ergy provided by sugars (presumably by facilitating the acquisition or catabolism of organic $\mathrm{N}$ and complex sugars in the environment). This is consistent with suggestions that $\mathrm{N}$ mineralizing processes in soils can be subject to strong $\mathrm{C}$ limitations (as opposed to limitations from organic $\mathrm{N}$ substrates or mineral N (Olander and Vitousek 2000). Because organic $\mathrm{N}$ compounds and organic $\mathrm{C}$ are bound together within soil organic matter, mineralization of proteins by microbes can increase the availability of 
a)
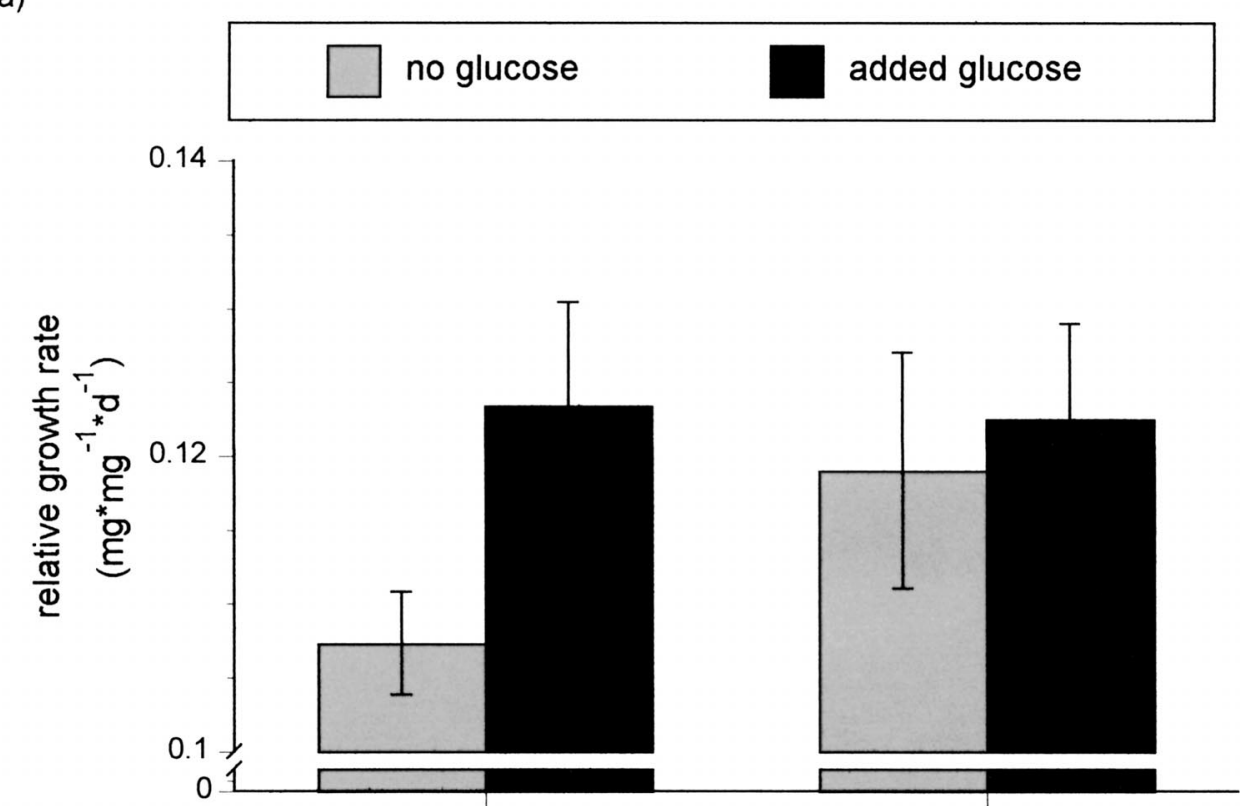

b)

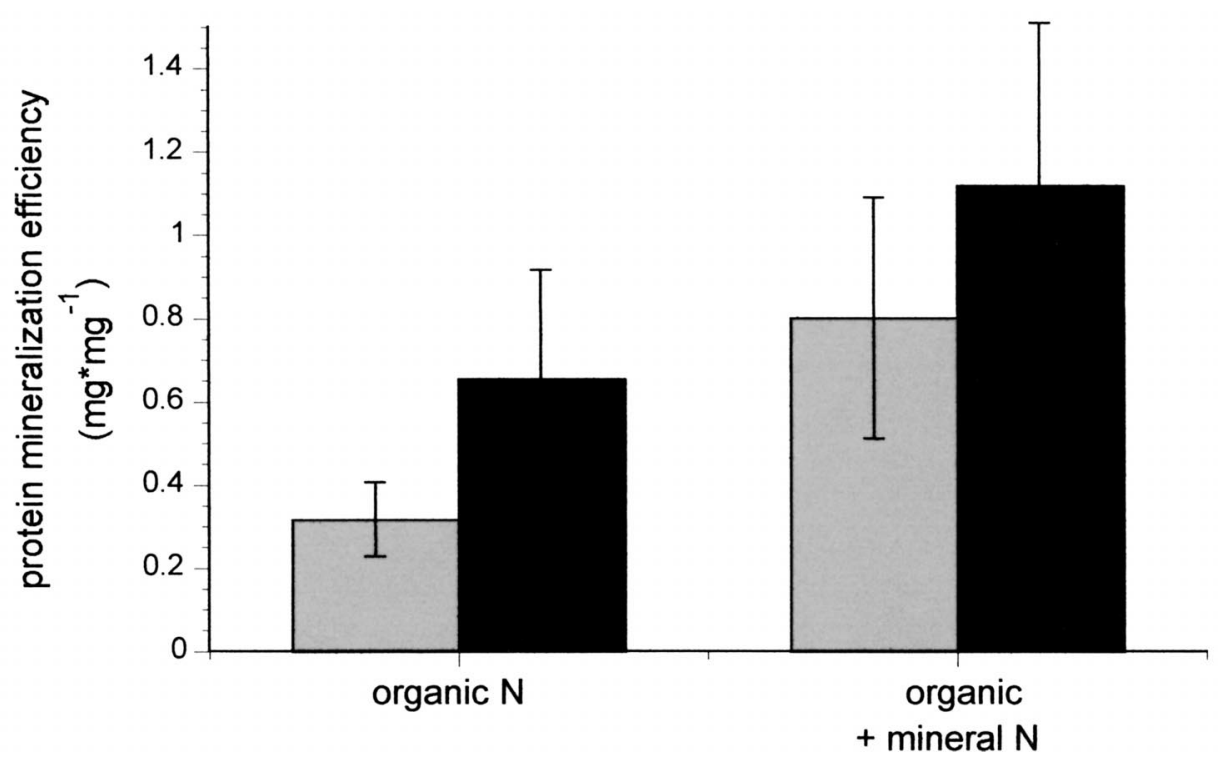

FIG. 1. Mean growth rate (a) and protein mineralization efficiency (b) of ten species of ectomycorrhizal fungi in response to manipulations of glucose and mineral nitrogen (least square means $\pm \mathrm{SE}$ ).

high-energy $\mathrm{C}$ compounds as well as assimilable $\mathrm{N}$ (McGill and Cole 1981). In the context of our experiments, addition of mineral $\mathrm{N}$ to the media stimulated protease production, which increased protein mineralization, $\mathrm{C}$ availability, and growth in the low sugar treatment. In contrast, mineral $\mathrm{N}$ mostly decreased growth in the high sugar treatment, but continued to stimulate mineralization. Our results indicate phenotypic plasticity in the allocation of $\mathrm{C}$ within mycelia of ectomycorrhizal fungi that favors $\mathrm{N}$ acquisition over growth.
The extent to which $\mathrm{N}$ availability eases $\mathrm{C}$ limitations of ectomycorrhizal fungi is relevant to understanding responses of microbial communities to $\mathrm{N}$ enrichment. Carbon allocation of trees to mycorrhizae tends to decrease in response to increased availability of mineral nutrients (Ekblad et al 1995, but see Wallander and Nylund 1991). The consequences for fungi will be eased if there is some substitutability of mineral $\mathrm{N}$ and $\mathrm{C}$. This may mean continued or even increased benefits to plant hosts of ectomycorrhizae in N-enriched forests (continued benefits of 


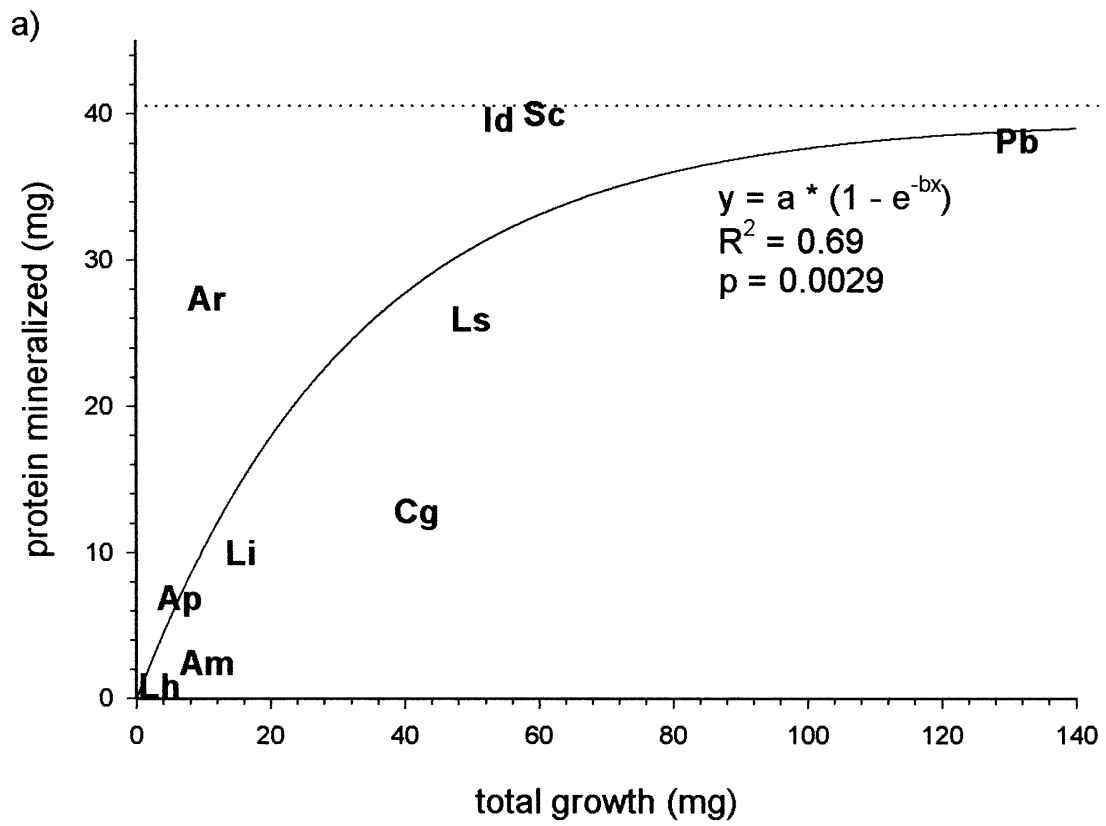

b)

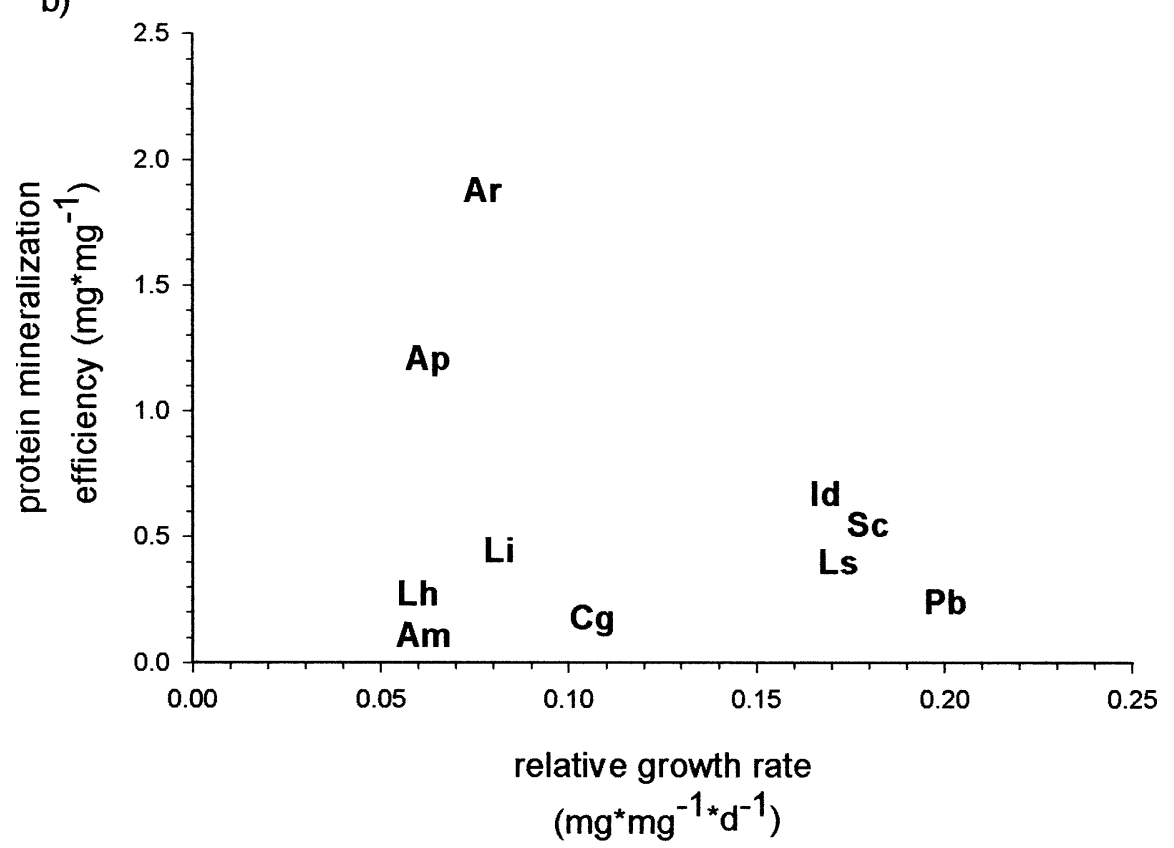

FIG. 2. Scatter plots of total growth vs protein mineralized (a) and relative growth rate vs. protein mineralization efficiency (b) of ten ectomycorrhizal fungi. Points are least square means for each fungus across all treatments. Maximum protein mineralization of $40.5 \mathrm{mg}$ (dotted line) was set by the medium. Solid line shows best fit saturation function where a $=39.57$ and $\mathrm{b}=0.0302 . \mathrm{Am}=$ Amanita muscaria, $\mathrm{Ap}=$ A. pantherina, $\mathrm{Ar}=$ A. rubescens, $\mathrm{Cg}=$ Cenococcum geophillum, $\mathrm{Id}=$ Inocybe dulcamera, $\mathrm{Lh}=$ Lactarius hepaticus, $\mathrm{Li}=$ L. indigo, $\mathrm{Ls}=$ Leccinum scabrum, $\mathrm{Pb}=$ Piloderma bicolor, $\mathrm{Sc}=$ Scleroderma citrina.

nutrient acquisition even with decreased $\mathrm{C}$ subsidies). One alternative is a general decrease in ectomycorrhizal fungi, which could be to the detriment of trees in acquiring $\mathrm{P}$, or in meeting $\mathrm{N}$ demands during occasional periods of low $\mathrm{N}$ availability. A third alternative is that fungal growth and metabolism are stimulated by $\mathrm{N}$ enrichment and the high sink strength in roots continues to draw carbohydrate resources from the tree to fungi. In the last case, $\mathrm{N}$ deposition could shift the relationship between trees and mycorrhizae towards parasitism (Francis and Read 1995, Johnson et al 1997, Graham and Eissenstat 1998). Additional studies could test the extent to which $\mathrm{N}$ enrichment increases $\mathrm{C}$ demands from fungi 
TABLE III. Spearman rank correlation matrix of physiological responses of ectomycorrhizal fungi to factorial design of carbon $(\mathrm{C})$ and nitrogen $(\mathrm{N})$. Correlations are based on coefficients from linear model of 2-way ANOVA for each fungus (see Methods). $\mathrm{N}=10$ fungi

\begin{tabular}{|c|c|c|c|c|c|c|c|c|}
\hline & A & B & $\mathrm{C}$ & $\mathrm{D}$ & $\mathrm{E}$ & $\mathrm{F}$ & $\mathrm{G}$ & $\mathrm{H}$ \\
\hline A. Relative growth rate & 1.00 & & & & & & & \\
\hline B. C growth response & -0.66 & 1.00 & & & & & & \\
\hline C. $\mathrm{N}$ growth response & -0.33 & 0.064 & 1.00 & & & & & \\
\hline D. $\mathrm{C} \times \mathrm{N}$ growth response & 0.097 & -0.30 & -0.08 & 1.00 & & & & \\
\hline E. Avg. mineralization efficiency & -0.055 & 0.094 & -0.05 & -0.32 & 1.00 & & & \\
\hline F. C mineralization response & -0.50 & 0.49 & -0.005 & -0.42 & 0.52 & 1.00 & & \\
\hline G. $\mathrm{N}$ mineralization response & -0.70 & 0.43 & 0.17 & -0.48 & 0.53 & 0.77 & 1.00 & \\
\hline \multicolumn{9}{|l|}{ H. $\mathrm{C} \times \mathrm{N}$ mineralization } \\
\hline response & -0.16 & -0.16 & -0.38 & 0.21 & -0.70 & -0.05 & -0.20 & 1.00 \\
\hline
\end{tabular}

by measuring carbohydrate depletion from the media.

Three-way interactions between sugar, mineral $\mathrm{N}$, and fungal species (TABLE I) indicated that relations between $\mathrm{C}$ and $\mathrm{N}$ requirements vary between species. We approached this study with an a priori prediction that fungi would exhibit one of two basic alternative strategies: (1) grow better on mineral N, respond little to carbohydrates, and produce little in the way of protease or (2) respond negatively or not at all to mineral nitrogen, grow better with more carbohydrates, and produce copious protease. Our results indicate that this was a simplification (FIGS. 2B, 3). However, there were some general patterns. Those fungi with high growth rates (positive scores on PC axis 1 in FIG. 3) tended to be those often classified ecologically as early- or multi-stage (or perhaps plastic) fungi. In contrast, those fungi with low growth rates and high mineralization efficiency are often characterized as late-stage (or K-selected) fungi. In $\mathrm{N}$-deposition scenarios, these latter fungi may tend to be less competitive and replaced by species from the

TABLE IV. Factor loadings for PCA analysis of physiological responses of 10 ectomycorrhizal fungi. PCA was based on correlation matrix in TABLE III

\begin{tabular}{lrrr}
\hline & \multicolumn{3}{c}{ PC } \\
\cline { 2 - 4 } & Axis 1 & Axis 2 & Axis 3 \\
\hline Relative growth rate & -0.175 & -0.491 & -0.355 \\
C growth response & 0.663 & 0.431 & 0.085 \\
$\mathrm{~N}$ growth response & 0.254 & -0.093 & 0.852 \\
$\mathrm{C} \times \mathrm{N}$ growth response & -0.567 & 0.163 & 0.266 \\
Avg. mineralization efficiency & 0.619 & -0.685 & -0.260 \\
$\mathrm{C}$ mineralization response & 0.815 & 0.162 & -0.352 \\
$\mathrm{~N}$ mineralization response & 0.896 & 0.114 & -0.114 \\
$\mathrm{C} \times$ N mineralization & & & \\
$\quad$ response & -0.453 & 0.732 & -0.387 \\
\% variance explained & 42.4 & 18.8 & 16.0 \\
\hline
\end{tabular}

former group. Species such as Cenococcum geophillum (positive scores on PG axis 3) may also tend to increase under $\mathrm{N}$ deposition by virtue of direct positive responses from addition of mineral N. Among the fungi in this study, those most likely to suffer from $\mathrm{N}$ deposition are Amanita pantherina and Inocybe dulcamera, as they had a strong dependency on sugar and addition of mineral $\mathrm{N}$ tended to reduce growth. These conclusions require that the fungal isolates used in this study be representative of the species. Variability among genetic isolates is well recognized (Finlay et al 1992, Keller 1996, Tibbett et al 1998, Chen et al 1999). It seems unlikely that intraspecific variability would be so great as to obscure the large differences indicated in this study, but additional research with replicate isolates collected from nature would be a valuable addition to our understanding of the physiological ecology of ectomycorrhizal fungi. A more important caveat to drawing inferences about changes in community composition is that our measurements described the behavior of these fungi in isolation from other members of the soil community. Species interactions in nature can be strongly influenced by factors other than intrinsic growth responses. Allelopathic interactions are likely to be of special importance to soil microbes (Blum 1995, Klopatek and Klopatek 1997, Blum et al 1999). Nonetheless, our results correspond to reports from Europe that forests experiencing intense atmospheric $\mathrm{N}$ deposition have also experienced declines in some of the same late-stage fungi tested here (Ohenoja 1988, Kuyper and deVries 1990, Arnolds 1991, Gulden et al 1993).

The autecological responses of fungi to mineral $\mathrm{N}$ and carbohydrates indicated by our study may provide a parsimonious foundation for understanding recent changes in abundance and diversity of ectomycorrhizal fungi in European forests and anticipating changes in other forests that are subject to chron- 


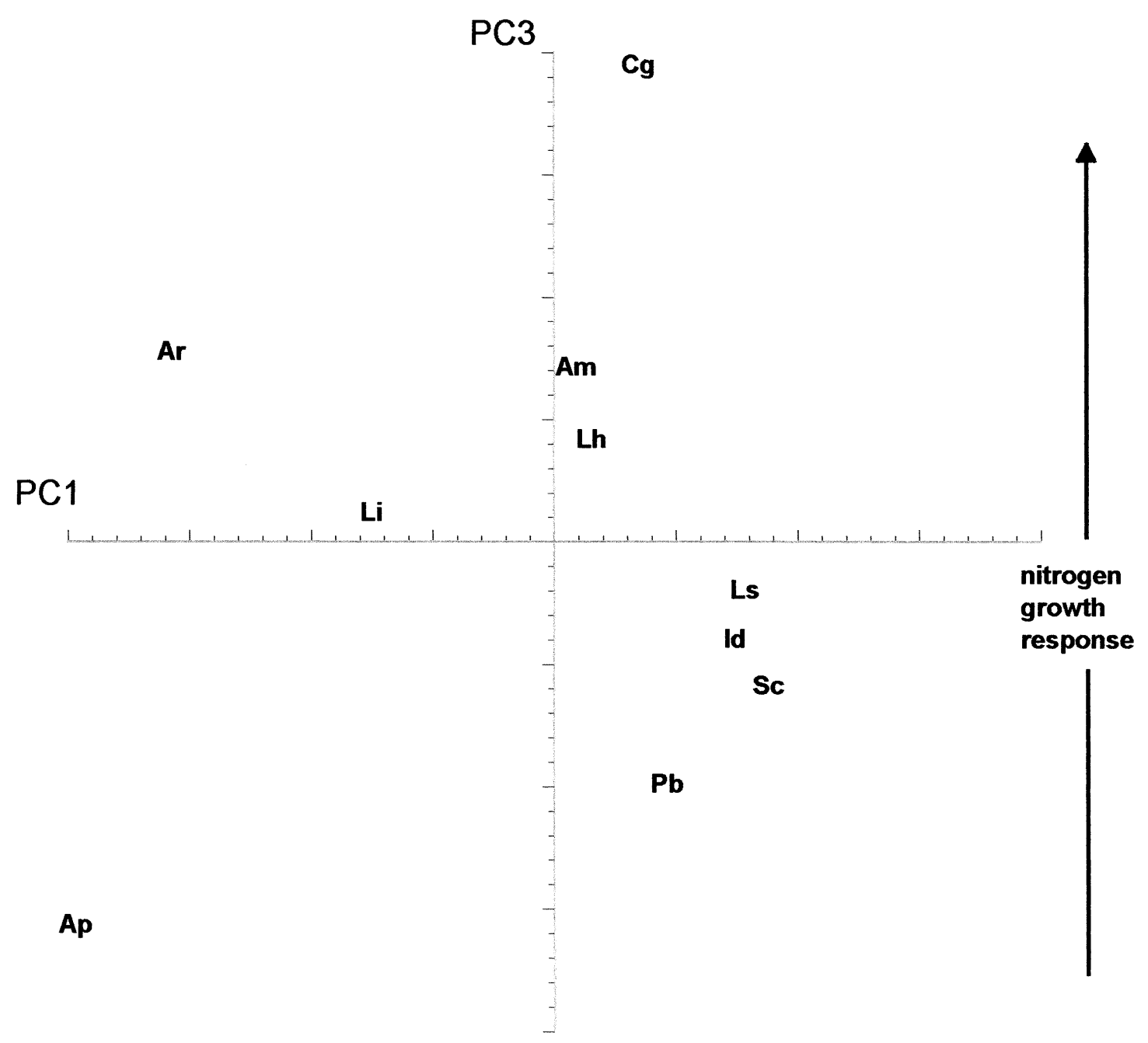

\section{high \\ mineralization efficiency}

high relative growth rate

FIG. 3. Plot of factor scores for ten ectomycorrhizal fungi along Principle Components axes 1 and 3. Am = Amanita muscaria, $\mathrm{Ap}=$ A. pantherina, $\mathrm{Ar}=$ A. rubescens, $\mathrm{Cg}=$ Cenococcum geophillum, $\mathrm{Id}=$ Inocybe dulcamera, Lh $=$ Lactarius hepaticus, $\mathrm{Li}=$ L. indigo, $\mathrm{Ls}=$ Leccinum scabrum, $\mathrm{Pb}=$ Piloderma bicolor, $\mathrm{Sc}=$ Scleroderma citrina.

ic $\mathrm{N}$ deposition. As a result of direct effects of increased mineral $\mathrm{N}$, and indirect effects on host tree $\mathrm{C}$ allocation, ectomycorrhizal fungi may: (i) become more expensive for hosts to maintain by virtue of their increased growth and metabolism, (ii) provide reduced benefits to their tree hosts because their mineralization services have less value, (iii) change in their community structure, (iv) contribute to increased leaching losses of nitrate by increasing the pools of mineral $\mathrm{N}$ in excess of biotic demands; and (v) influence $\mathrm{C}$ flux through forests ecosystems, either directly through decomposition or indirectly by influencing host trees and altering primary productivity.

\section{ACKNOWLEDGMENTS}

We thank Orson Miller and John Walker for supplying some of the cultures used in this study. Yeejin Kim and Betsy Lewis aided in the maintenance of cultures and initial enzyme analyses. Two anonymous reviewers contributed to the improvement of this manuscript. Funding was provided by Sigma Xi Grants in Aid of Research and by Dartmouth College Department of Biological Sciences.

\section{LITERATURE CITED}

Aber JD. 1992. Nitrogen cycling and nitrogen saturation in temperate forest ecosystems. Trends Ecol Evol 7:220224. 
Arnolds E. 1988. The changing macromycete flora in the Netherlands. Trans Br Mycol Soc 90:391-406.

- 1991. Decline of ectomycorrhizal fungi in Europe. Agric Ecos Environ 35:209-244.

Ayres MP. 1993. Global change, plant defense, and herbivory. In: Kareiva PM, Kingsolver JG, Huey RB, eds. Biotic interactions and global change. Sunderland, Massachusetts: Sinauer Associates. p 75-94.

Baar J, Comini B, Elferink MO, Kuyper TW. 1997. Performance of four ectomycorrhizal fungi on organic and inorganic nitrogen sources. Mycol Res 101:523-529.

Bardgett RD, McAlister E. 1999. The measurement of soil fungal: bacterial biomass ratios as an indicator of ecosystem self-regulation in temperate meadow grasslands. Biol Fert Soils 29:282-290.

Bidartondo MI, Ek H, Wallander H, Soderstrom B. 2001. Do nutrient additions alter the carbon sink strength of ectomycorrhizal fungi? New Phytol 151:543-550.

Bloom AJ, Chapin FS III, Mooney HA. 1985. Resource limitation in plants-an economic analogy. Annu Rev Ecol Syst 16:363-392.

Blum U. 1995. The use of plant-microbe-soil systems for characterizing allelopathic interactions involving phenolic acids. J Nematol 27:493.

Blum U, Shafer SR, Lehman ME. 1999. Evidence for inhibitory allelopathic interactions involving phenolic acids in field soils: concepts vs. an experimental model. Critical Reviews in Plant Sciences 18:673-693.

Bradbury SM, Danielson RM, Visser S. 1998. Ectomycorrhizas of regenerating stands of lodgepole pine (Pinus contorta). Can J Bot 76:218-227.

Carreiro M, Sinsabaugh R, Repert D. 1996. Effects of chronic of $\mathrm{N}$-addition on microbial biomass, extracellular enzyme allocation and mass loss of decaying forest leaf litter. Bulletin of the Ecological Society of America 77: 71.

Chalot M, Brun A. 1998. Physiology of organic nitrogen acquisition by ectomycorrhizal fungi and ectomycorrhizas. FEMS Microbiol Rev 22:21-44.

Chapin FS III. 1980. The mineral nutrition of wild plants. Annu Rev Ecol Syst 11:233-260.

Chen A, Chambers SM, Cairney JWG. 1999. Utilization of organic nitrogen and phosphorus sources by mycorrhizal endophytes of Woollsia pungens (Cav.) F. Muell. (Epacridaceae). Mycorrhiza 8:181-187.

Cohen BL. 1981. Regulation of protease production in Aspergillus. Trans Brit Mycol Soc 76:447-450.

Diekmann M, Brunet J, Ruhling A, Falkengren-Grerup U. 1999. Effects of nitrogen deposition: results of a temporal-spatial analysis of deciduous forests in South Sweden. Plant Biology 1:471-481.

Dighton J. 1991. Acquisition of nutrients from organic resources by mycorrhizal autotrophic plants. Experientia 47:362-369.

Dighton J, Poskitt JM, Howard DM. 1986. Changes in occurrence of basidiomycete fruit bodies during forest stand development: with specific reference to mycorrhizal species. Trans Brit Mycol Soc 87:163-171.

Dunne C, Crowley JJ, Moenne-Loccoz Y, Dowling DN, de Bruijn FJ, O’Gara F. 1997. Biological control of Pythium ultimum by Stenotrophomas maltophilia w81 is mediated by an extracellular proteolytic activity. Microbiology 143:3921-3931.

Ek H. 1997. The influence of nitrogen fertilization on the carbon economy of Paxillus involutus in ectomycorrhizal association with Betula pendula. New Phytol 135: 133-142.

Ekblad A, Wallander H, Carlsson R, Hussdanell K. 1995. Fungal biomass in roots and extramatrical mycelium in relation to macronutrients and plant biomass of ectomycorrhizal Pinus sylvestris and Alnus incana. New Phytol 131:443-451.

Finlay RD, Frostegard A, Sonnerfeldt AM. 1992. Utilization of organic and inorganic nitrogen sources by ectomycorrhizal fungi in pure culture and in symbiosis with Pinus contorta Dougl ex. Loud. New Phytol 120:105115.

Finlay RD. 1992. Mycorrhiza and carbon flow to the soil. In: Allen M, ed. Mycorrhizal functioning. London, UK: Chapman and Hall. p 134-160.

Fogel R, Hunt G. 1979. Fungal and arboreal biomass in a western Oregon Douglas-fir ecosystem: distribution patterns and turnover. Can J For Res 9:245-256.

France RC, Reid CPP. 1983. Interactions of nitrogen and carbon in the physiology of ectomycorrhizae. Can J Bot 61:964-984.

, - 1984. Pure culture growth of ectomycorrhizal fungi on inorganic nitrogen sources. Microb Ecol 109:187-195.

Francis R, Read DJ. 1995. Mutualism and antagonism in the mycorrhizal symbiosis, with special reference to impacts on plant community structure. Can J Bot 73(Supp. 1):S1301-S1309.

Graham JH, Eissenstat DM. 1998. Field evidence for the carbon cost of citrus mycorrhizas. New Phytol 140:103110.

Gulden G, Hoiland K, Bendiksen K, Brandrud TE, Foss BS, Jenssen HB, Laber D. 1993. Macromycetes and air pollution; Mycocoenological studies in three oligotrophic spruce forests in Europe. Bibliotheca Mycologia 144. Berlin: J Cramer. 81 p.

Gundersen P. 1998. Effects of enhanced nitrogen deposition in a spruce forest at Klosterhede, Denmark, examined by moderate $\mathrm{NH}_{4} \mathrm{NO}_{3}$ addition. Forest Ecol Manage 101:251-268.

Hatch DJ, Lovell RD, Antil RS, Jarvis SC, Owen PM. 2000. Nitrogen mineralization and microbial activity in permanent pastures amended with nitrogen fertilizer or dung. Biol Fert Soils 30:288-293.

Herms DA, Mattson WJ. 1992. The dilemma of plants: to grow or defend. Quart Rev Biol 67:283-335.

Hintikka V. 1988. On the macromycete flora in oligotrophic pine forests of different ages in South Finland. Acta Bot Fennica 136:89-94.

Hintze JL. 2002. NCSS Statistical System. Kaysville, Utah: NCSS Inc.

Jefferies RL, Maron JL. 1997. The embarrassment of riches: atmospheric deposition of nitrogen and community and ecosystem processes. Trends Ecol Evol 12:74-78.

Johnson NC, Graham JH, Smith FA. 1997. Functioning and 
mycorrhizal associations along the mutualism-parasitism continuum. New Phytol 135:575-586.

Jonasson S, Michelsen A. 1996. Nutrient cycling in subarctic and arctic ecosystems, with special reference to the Abisko and Tornetrask region. In: Karlsson PS, Callaghan TV, eds. Ecological Bulletins; Plant ecology in the subarctic Swedish Lapland. p 45-52.

Jonsson L, Dahlberg A, Nilsson M-C, Karen O, Zackrisson O. 1999. Continuity of ectomycorrhizal fungi in selfregenerating boreal Pinus sylvestris forests studied by comparing mycobiont diversity on seedlings and mature trees. New Phytol 142:151-162.

Keller G. 1996. Utilization of inorganic and organic nitrogen sources by high-subalpine ectomycorrhizal fungi of Pinus cembra in pure culture. Mycol Res 100:989-998.

Klopatek CC, Klopatek JM. 1997. Nitrifiers and mycorrhizae in pristine and grazed pinyon-juniper ecosystems. Arid Soil Res Rehab 11:331-342.

Kuyper TW, deVries BWL. 1990. Effects of fertilization on the mycoflora of a pine forest. Commun Biol Station 351:102-111. Wageningen Agric Univ Papers 90-6.

Last FT, Dighton J, Mason PA. 1987. Successions of sheathing mycorrhizal fungi. Tree 2:157-161.

Leake JR, Read DJ. 1991. Proteinase activity in mycorrhizal fungi. 3. Effects of protein, protein hydrolysate, glucose and ammonium on production of extracellular proteinase by Hymenoscyphus ericae (Read) Korf and Kernan. New Phytol 117:309-317.

Lilleskov EA, Fahey TJ, Lovett GM. 2001. Ectomycorrhizal fungal aboveground community change over an atmospheric nitrogen deposition gradient. Ecol Appl 11(2):397-410.

Mason PA, Wilson J, Last FT, Walker C. 1983. The concept of succession in relation to the spread of sheathing mycorrhizal fungi on inoculated tree seedlings growing in unsterile soils. Plant Soil 71:247-256.

McGill WB, Cole CV. 1981. Comparative aspects of cycling of organic C, N, S and P through soil organic matter. Geoderma 26:267-286.

McNulty SG, Aber JD. 1993. Effects of chronic nitrogen additions on nitrogen cycling in a high-elevation sprucefir stand. Can J For Res 23:1252-1263.

Näsholm T, Ekblad A, Nordin A, Giesler R, Hogberg M, Hogberg P. 1998. Boreal forest plants take up organic nitrogen. Nature 392:914-916.

Neter J, Wasserman W. 1974. Applied linear statistical models. Homewood, Illinois: Richard Irwin, Inc.

Ohenoja E. 1988. Effect of forest management procedures on fungal fruit body production in Finland. Acta Bot Fennica 136:81-84.

Ohtonen R. 1994. Accumulation of organic matter along a pollution gradient: application of Odum's theory of ecosystem energetics. Microb Ecol 27:43-55.

Olander LP, Vitousek PM. 2000. Regulation of soil phosphatase and chitinase activity by $\mathrm{N}$ and $\mathrm{P}$ availability. Biogeochemistry 49:175-190.

Plassard C, Scheromm P, Mousain D, Salsac L. 1991. Assimilation of mineral nitrogen and ion balance in the two partners of ectomycorrhizal symbiosis: data and hypothesis. Experientia 47:340-349.
Read DJ. 1991. Mycorrhizas in ecosystems-nature's response to the "Law of the Minimum." In: Hawksworth DL, ed. Frontiers in mycology. Regensburg: C.A.B. International. p 101-130.

Schulze ED, Chapin FS III. 1987. Plant specialization to environments of different resource availability. In: Schulze ED, Zwoelfer $\mathrm{H}$, eds. Potentials and limitations of ecosystem analysis. Ecological Studies. Berlin, Heidelberg, New York, New York. p 120-148.

Senn-Irlet B, Bieri G. 1999. Sporocarp succession of soilinhabiting macrofungi in an autochthonous subalpine Norway spruce forest of Switzerland. Forest Ecol Manage 124:169-175.

Sinclair TR, Park WI. 1993. Inadequacy of the Liebig limiting-factor paradigm for explaining varying crop yields. Agron J 85:742-746.

Sinsabaugh RL. 1994. Enzymatic analysis of microbial pattern and process. Biol Fert Soils 17:69-74.

Sinsabaugh RL, Antibus RK, Linkins AE, McClaugherty CA, Rayburn L, Repert D, Weiland T. 1993. Wood decomposition-nitrogen and phosphorus dynamics in relation to extracellular enzyme activity. Ecology 74:15861593.

Sinsabaugh RL, Moorhead DL. 1994. Resource allocation to extracellular enzyme production-a model for nitrogen and phosphorus control of litter decomposition. Soil Biol Biochem 26:1305-1311.

Smith FA, Smith SE. 1990. Solute transport at the interface-ecological implications. Agric Ecosyst Environ 28:475-478.

Smith SE, Read DJ. 1997. Mycorrhizal symbiosis. 2nd ed. San Diego, California: Academic Press. 605 p.

Termorshuizen A, Schaffers A. 1987. Occurrence of carpophores of ectomycorrhizal fungi in selected stands of Pinus sylvestris in the Netherlands in relation to stand vitality and air pollution. Plant Soil 104:209-217.

. 1991. The decline of carpophores of ectomycorrhizal fungi in stands of Pinus sylvestris L. in The Netherlands: possible causes. Nova Hedwigia 53:267289.

Tibbett M, Sanders FE, Minto SJ, Dowell M, Cairney JWG. 1998. Utilization of organic nitrogen by ectomycorrhizal fungi (Hebeloma spp.) of arctic and temperate origin. Mycol Res 102:1525-1532.

Visser S. 1995. Ectomycorrhizal fungal succession in jack pine stands following wildfire. New Phytol 129:389-401.

Vitousek PM, Aber JD, Howarth RW, Likens GE, Matson PA, Schindler DW, Schlesinger WH, Tilman DG. 1997. Human alteration of the global nitrogen cycle: sources and consequences. Ecol Appl 7:737-750.

Vogt KA, Grier CG, Meier CE, Edmonds RL. 1982. Mycorrhizal role in net primary production and nutrient cycling in Abies amabilis ecosystems in western Washington. Ecology 63:370-380.

, Publicover DA, Bloomfield J, Perez JM, Vogt DJ, Silver WL. 1993. Belowground responses as indicators of environmental change. Env Exper Bot 33:189-205.

Wallander H. 1995. A new hypothesis to explain allocation of dry matter between mycorrhizal fungi and pine 
seedlings in relation to nutrient supply. Plant Soil 168169:243-248.

Wallander H, Nylund J-E. 1991. Effects of excess nitrogen on carbohydrate concentration and mycorrhizal development of Pinus sylvestris L. seedlings. New Phytol 119: 405-411.

Wallander H, Arnebrant K, Dahlberg A. 1999. Relationships between fungal uptake of ammonium, fungal growth and nitrogen availability in ectomycorrhizal Pinus sylvestris seedlings. Mycorrhiza 8:215-223.

Wallenda T, Kottke I. 1998. Nitrogen deposition and ectomycorrhizas. New Phytol 139:169-187.

Wallenda T, Schaeffer C, Einig W, Wingler A, Hampp R,
Seith B, George E, Marschner H. 1996. Effects of varied soil nitrogen supply on norway spruce (Picea abies [L] Karst). 2. Carbon metabolism in needles and mycorrhizal roots. Plant Soil 186:361-369.

Zaman M, Di HJ, Cameron KC, Frampton CM. 1999. Gross nitrogen mineralization and nitrification rates and their relationships to enzyme activities and the soil microbial biomass in soils treated with dairy shed effluent and ammonium fertilizer at different water potentials. Biol Fert Soils 29:178-186.

Zhu H, Dancik BP, Higginbotham KO. 1994. Regulation of extracellular proteinase production in an ectomycorrhizal fungus Hebeloma crustuliniforme. Mycologia 86: 227-234. 